\title{
Weaving this and that way: Ghost net connections in an Aboriginal community in northern Australia
}

\author{
Emily Munro-Harrison \\ Research Fellow \\ Melbourne School of Population and Global Health \\ The University of Melbourne \\ emily.munro@unimelb.edu.au
}

Keywords: Objects of governance, Aboriginal, ghost net, weaving

Walking along the shore of North Goulburn Island we look for rope and fishing nets discarded or cut loose by commercial fishing boats. These nets are given the name 'ghost nets' as they drift ownerless through the sea. I am here with the manager of the art centre on Goulburn Island and the manager of the Community Development and Employment Projects (CDEP) ${ }^{1}$ who invited me to go out on the sea with them on my first weekend in Warruwi. I am volunteering at the Mardbalk Arts and Craft Centre, as an assistant in the art centre and to conduct research for my Master of Environment thesis. We collect the bits of rope as we find them, tugging and pulling them out of the sand where they are deeply buried. As we walk along the shoreline I can see the beach as a kind of treasure trove, where all the bits and pieces of things end up after they are thrown 'away', into the unknown. My feet are scorching on the hot white and black sand, marked by goat tracks in every direction. In between buoys, seaweed, single shoes, glass and goat poo, we come across our desired objects. The rope known as 'ghost net' is considered by environmentalists to pose serious environmental risks as it can tangle and trap sea creatures, killing or seriously injuring the wildlife and end up as pollution on beaches in the region. However, rubbish collection is not our primary purpose. We are scavenging these ropes for the art centre where they are used to produce sculptural artwork.

In the month prior to my arrival at Warruwi, some women came to Mardbalk Arts and Crafts Centre to instruct the artists in the use of ghost net as a fibre to weave bags and sculptures. Bright nylon thread is used to stitch the ghost net bits together. In some communities such as Warruwi, where paid community work still exists under the banner of CDEP, workers assist in removing ghost nets from the shorelines. I can already tell that this is hard work - not only is it hot in the direct sun, but the sand burying the rope is heavy and wet and sometimes the rope is quite embedded.

1. The Community Development and Employment Projects (CDEP) program funded by the Australian Government has operated in Indigenous communities as a paid community work initiative for Indigenous people since 1977. CDEP provides activities and work that contribute to the maintenance of communities and develop participants' skills and employability. In recent years, the program has undergone a number of evaluations and is being scaled back and integrated into the Remote Jobs and Communities Programme (RJCP). This shift raises questions about the future shape programs and community work may take, and the structures and support that will replace the CDEP.

Retrieved from the Australian Government Department of Human Services website: http://www.humanservices.gov.au/customer/ services/centrelink/community-development-employment-projects\#a4 (August, 2014) 
On my first day at Mardbalk, I find myself surrounded by the earthy scent of moldering wood, paint, pandanus leaves ${ }^{2}$ and other art centre smells. The manager gives me a quick tour of the brightly coloured building. There aren't many paintings in the centre, but there are a lot of baskets, jewelry and carvings. There is a blue tarp on the ground in the front room with a few cushions in a circle, various bits of ghost net and dried pandanus, along with empty tea mugs and several friendly camp dogs. This is the area the women sit and weave during the working day. The other main public room of the centre contains several large black and white photographs of people from the days when Warruwi was a mission settlement. The images are of happy looking young Aboriginal people. In one photo, there is a beautiful young woman smiling shyly at the camera and cradling a tiny baby; in another, there are several people in a bark canoe dragging a turtle out of the water. They are very clear and beautiful pictures and the manager tells me that they are very old. The manager takes me into the back room, which has a large padded table used for screen-printing.

'Can you photograph the ghost net work?' She asks me, gesturing to a pile of brightly coloured creations stacked on one corner of the table. 'They need to go up on the website, so I was thinking you might be able to Photoshop them a bit, make them look even prettier?' She looks from my sunburnt face (from the boat trip) to the ghost nets. I agree. 'You'll have to get up on the table and try and not cast a shadow over them,' she advises. Pointing to a small wooden stool as my means for getting onto the table, she leaves me to it.

Once the small digital camera is in my possession, I clamber up onto the table noting the dusty red marks my feet have already made on the white sheet that is meant to serve as a backdrop. I place a small brightly coloured ghost net bag in the centre of the white sheet and do my best to make no shadow as I take a photo. I contort my body and duck so as not to hit my head on the ceiling fan, which is spinning slowly and slightly off kilter.

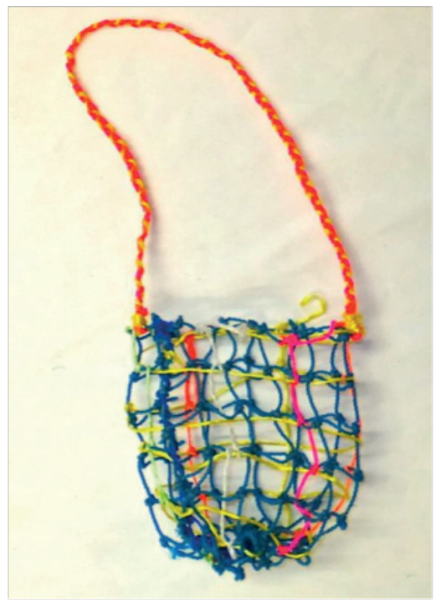

I can hear voices in the next room and turn to see the art centre manager enter with one of the artists. She introduces me - I feel self-conscious about not only my pose and elevated height, but also of my sunburnt face. I struggle inelegantly down from the table and shake hands with the artist who is eyeing me with an amused smile.

'I'm just taking some photos of the ghost net for the website', I try and explain. The artist smiles and nods at me. 'So is one of these yours?' I ask pointing to the pile of ghost net weavings. She nods her head and removes a bag to show me. It is green with bright pink nylon stitching. We admire her handy work, and then she tells me she is going to get a cup of tea. She doesn't come back.

I don't really know what to do with myself in the art centre - aside from the jobs the manager gives me. I am eager to see how the centre operates, how things are done and who and what is involved. I feel a great sense of discomfort when I 'hang around' - not wanting to make people feel watched or studied. I try to figure out how best to collect information and try to get people to talk to me about daily workings. I also don't want to upset the operations of the art centre, so it all feels like quite a messy dilemma. I concentrate on the task at hand - taking photos of the ghost net weavings, standing on the table in funny positions, trying not to hit my head on the fan. As the day progresses, people come in and out of the room, introduce

2. Pandanus is a spiny-leafed tree/shrub found in the north of Australia. In Warruwi and other communities in Arnhem Land, the leaves are collected, split, dyed and dried and used to weave floor mats, bags, hats and sculptures as well as many other things. 
themselves; nod at me, or just ignore me. The CDEP manager comes in and laughs at my sunburned face. The local Police officers come by and introduce themselves. Some children run in and out of the room giggling and yell 'HELLO' at me as they scuttle away again.

Once I have finished photographing the art works, I take the camera and sit in the office with the art centre manager. She sets me up on a beautiful shiny new Mac computer in the corner, and explains the machine is part of the language program to record and maintain the local language - Maung, which is considered in danger of being lost as there aren't many native speakers left. I get to work on the images, making them brighter and clearer, all the while enjoying the airconditioning offered by this room and the frequent visits by the artists who come by for tea, biscuits and chats with the manager. I get to hear a bit of gossip and also to observe some of the interactions people have, how they work together, where difficulties lie. A couple comes in, smiling shyly at the manager. They ask her if she can help them with a banking query. They hand her a letter, she reads it; they discuss the issue. I finish the images and excuse myself from the office - it seems inappropriate for me to be in there.

I head into the main art room where some artists are sitting on cushions on the floor weaving some are using pandanus and some are using ghost net. A man is sanding the outside of a log, making it smooth and light brown. He explains it is a hollow $\log ^{3}$ and will paint the outside. A woman is sitting at the table with a cup of tea, a little bit away from the group. I sit on a plastic chair next to her. She has been most friendly and welcoming to me. She has a small ghost net bag in front of her. I ask her about it. She uses gestures as she explains what she has done to make it. She asks for a lighter and I retrieve one from the office. She uses it to singe the ends of the nylon twine together. I can smell the acrid burnt plastic smell as she pinches and twists the melted ends. She shows me her handy work. I nod and smile. The couple from the office exit a short time later. They seem happy as though the issue they came about has been resolved. They leave the art centre quietly.

As the day progresses I move back and forth from room to room, photographing completed ghost net sculptures, editing them on the Mac in the office, and trying to talk to the artists as they go about their business. The friendly woman who showed me how to singe the twine together is polite as I sit down next to her on the tarp on the floor. The man who was sanding the log asks the women to show me how to weave with the net - and so the friendly woman shows me how to stitch ghost net together using nylon twine. I decide to make a bag and use faded green ghost net, fraying at the edges, and a red nylon twine. The artist instructing me is making a large turtle from the same green ghost net - it is going to be a mat or a sculpture to hang on the wall she tells me.

In the evening I walk to the beach with the art centre manager, and we hold our noses as the dogs following us chew on the turtle intestines and shells left on the beach after someone has been hunting. The manager explains to me that you can usually find a small hole in the shell of the hunted turtles where the spear went in. People go out on boats and catch turtles for eating. I think of the photos in the art centre of the people dragging the turtle into the boat, and of the turtle ghost net sculpture the artist is making. I feel like the threads of knowledge and elements of the community are starting to come together to provide me with just a little bit of an idea of how things work.

\section{Object in play}

As discussed in the introductory piece by Helen Verran, the French philosopher Michel Serres (1995) uses a description of children playing with a ball to enable us to see the ways in which objects have their own ways of knowing and governing.

3. Hollow logs are traditional coffins where a deceased person's bones are placed. The outside of the log is painted with a set of designs that represents the family and group to which they belong. 
Look at those children out there playing ball. The clumsy ones are playing with the ball as if it were an object, while the more skillful ones handle it as if the ball were playing with them: they move and change position according to how the ball moves and bounces. ... The ball is creating the relationships between [the children]. It... creates their team, knows itself and represents itself... It is the ball that is playing with the children. (p.47)

Rather than a game of soccer, this story is of the networks and interactions that are created through the game that is formed by the tangling and weaving of the ghost net throughout the community of Warruwi.

For me, the weaving of ghost nets is useful for my role as an ethnographer as it provides an intelligible background for me in figuring out my place and ways to be useful in the art centre. The ghost net brings me in with a purpose, I become a photographer, an editor, a weaver and a temporary member of the art centre community. Teams exist and are created through the activity of the ghost net, sometimes without participants even realising they are involved in the game at all. The ghost net is thrown into play by the fishermen on the boats that discard it, perhaps assuming with some correctness that they will not be held accountable for their actions, and without the recognition of the net being an object of governance within the fishing industry. The ghost net washes up on the shorelines of Goulburn and the surrounding islands, into the lives and daily doings of other people and entities who also become teams: the community workers collecting it; the instructors teaching with it; the art centre accepting it as a fibre; the artists weaving with it as a fibre; and the consumers purchasing it as an art and educational piece. The ghost net is also a political tool in the environmental sector, highlighting the issue of environmental hazard and excessive waste, whilst also modeling how to upcycle materials into useful/usable items.

When I arrived in Warruwi, ghost net was still working its way into being integrated into the 'normal' governmentality of the art centre, and so was operating on its own terms as an object of governance - taking me on its evolving journey - as it was pulled out of the sand and integrated into the business of the art centre and the community. At that moment, the agency of the ghost net was weaving and connecting different elements of the community together in a more formal way, obvious to outsiders such as myself. The ghost net allowed me to weave with it, and to see the obvious path it was making into the art centre and beyond into the community. The play was interactive, multiple ways, and the ghost net was certainly an active and directing participant.

The bag I made out of ghost net under the guidance of one of the artists at the centre was a little clumsy - not at all pretty. I created a drawstring and straps so it could be used as a kind of backpack. I gave it to the CDEP manager before I left - as a thank you for the outing he took the art centre manager and I on the first weekend after my arrival. He looked at it, smiled and said 'I found this rope' and gestured to the green fraying and faded net I used to make the bag.

\section{References}

Department of Human Services, Australian Government, Community Development Employment Projects Participant Supplement. Retrieved from http://www.humanservices.gov.au/customer/ services/centrelink/community-development-employment-projects\#a4

Serres, M. (1995). Angels. A Modern Myth. Paris, France: Flammarion. 